\title{
Measurement of Outside Thread Pitch Distance Results of TONGTAI TCS 1500[M] CNC Lath Using Profile Projector
}

\author{
Jaja Miharja $^{1, a)}$, Heru Santoso ${ }^{1}$, Hery Adrial $^{1}$, Muhamad Japar ${ }^{1}$ \\ ${ }^{1}$ Program Studi Teknik Mesin, Universitas Pamulang, Jl. Surya Kencana No. 1, Tangerang Selatan, Indonesia \\ E-mail: a) dosen01292@unpam.ac.id
}

Received :22 Oktober 2021

Revision :11 November 2021

Accepted:21 Noverber 2021

\begin{abstract}
Research has been carried out on the Measurement of the Outer Thread Pitch Distance from the Tongtai Tcs 1500[M] Cnc Lathe Using a Projector Profile. The use of a screw system to unite two components, is almost always found in all industrial technology results from the form of industrial technology with a low level of accuracy (rough) to a very high level of precision (precision). Therefore the screw system has become one of the important factors in industrial progress in all types of production. The higher the level of a component made means the higher the level of accuracy of the thread system. In this study, calculations were carried out to determine the level of precision of a thread made through the machining process using a TONGTAI TCS 1500 [M] CNC lathe. The precision measurement was carried out by measuring using a dimension measuring instrument, namely Profile Projector type HST-CPJ-3000/3000Z. To find out the average value and the value of the screw deviation, a research and measurement process was carried out with several product samples or test objects (sample A, sample B, sample C) where each sample was the same size, namely M15 $\times 50 P 1.5$. The first measurements were made on the major and minor diameters. Because this measurement is more focused on the level of precision of the thread pitch distance, the second measurement is carried out by measuring the dimensions of the distance between the pitches as much as $N=10$. From the 10 measuring points of the thread pitch distance, different average values and deviation values will be produced although in the same size. The purpose of this study was to determine the level of pressure of a thread made through a machining process which in this study used a CNC TONGTAI TCS 1500 [M] lathe. it is known that the overall average value of the three samples is with a major diameter $=14,949 \mathrm{~mm}$, a minor diameter $=$ $13,219 \mathrm{~mm}$, and a thread pitch distance $=1.5309 \mathrm{~mm}$.
\end{abstract}

Keywords: Measurement, Dimension, Pitch, Thread, Profile Projector, CNC TONGTAI TCS 1500[M].

\section{INTRODUCTION}

The use of a threaded system for joining two components is found in almost all technological results. From the results of industrial technology with a low level of accuracy (rough) to industrial products with a very high level of accuracy (precision), it cannot be separated from the thread. The thread system has become one of the important factors in industrial progress in all types of production. The higher the level of a component made means the higher the level of accuracy of the thread system. To be able to make threaded components, it is necessary to learn the ins and outs of threads, especially in terms of measurement systems. The distance between the peaks of the threads, which is also known as the pitch, is a dimension that has a large enough influence on the thread [1].

Because if the distance between the peaks of one thread and another is not the same, then this thread cannot be paired with other threads with the same distance from the peaks of each thread. Even if it is possible, of course, by being forced, which in the end will also damage the correct thread. As a result, the pairing of several components in one unit cannot last long. So, in the process of making threads, care must be taken to ensure that errors that occur at the top of the thread are still within the allowable limits. With a CNC-controlled lathe, the thread turning process becomes very efficient and effective, because it is possible to make threads with a wide range of pitches in a relatively fast and precise time [2]. 
This study was conducted to determine whether the peak distance of the threaded lathe is in accordance with the specifications. The research was conducted by using a profile projector method to measure the thread depth, thread angle \& outer thread pitch of the lathe [3]. Profile projector (optical comparator / shadowgraph) is an optical measurement device that enlarges the workpiece surface and is projected on a linear / circular scale [4].

With this measurement, it is hoped that it can be known whether the outer thread pitch distance of the lathe shows the size that is in accordance with its specifications. In addition, the results of measuring the outer thread pitch distance of the lathe were validated using a profile projector measuring instrument which has a higher level of accuracy compared to other measuring instruments [5].

\section{METHODS}

The research method in this research follows the flow chart as shown in the figure.

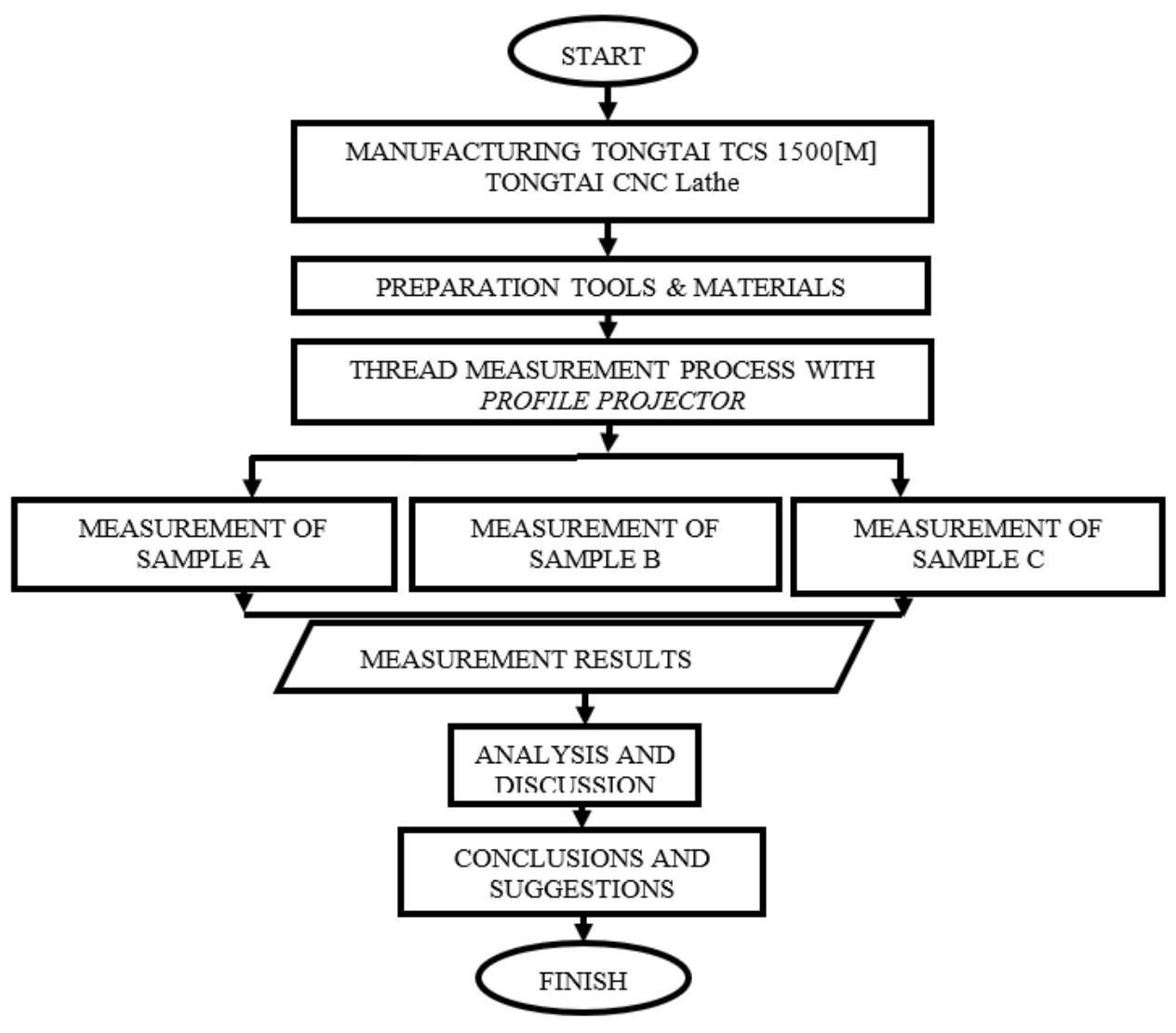

Figure 1. Research Method Flowchart

The initial step taken in this research is the preparation of the M15 Threaded test object material, a measuring instrument that is appropriate or supports the research. After that, measurements were made using a dimension measuring instrument, namely Profile Projector. Before measuring the dimensions of the outer thread pitch distance from the lathe, the measuring instrument was calibrated first so that the actual measurement results with the accuracy of the measuring instrument were in accordance with the standard. Calibration is translated as an action to maintain and ensure the quality of the results of the measuring instrument so that it functions properly. 


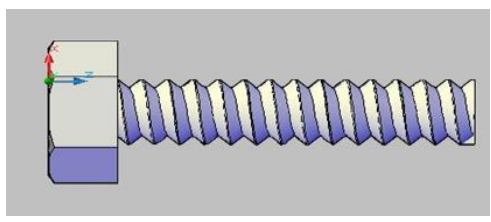

Figure 2. Treaded M15

\section{RESULT AND DISCUSSION}

The results of measuring the threaded pich distance can be seen in Table 1 .

Table 1. Thread Pitch Distance Measurement Data

\begin{tabular}{lccc}
\hline & \multicolumn{3}{c}{$\begin{array}{c}\text { Major diameter measurement results, } \\
\text { minor and Thread Pitch Distance (mm) }\end{array}$} \\
\cline { 2 - 4 } Measurement to & $\begin{array}{c}\text { M15 Threaded A } \\
\text { (Thread pitch }\end{array}$ & $\begin{array}{c}\text { M15 Threaded B } \\
\text { (Major diameter }\end{array}$ & $\begin{array}{c}\text { M15 Threaded C } \\
\text { (Minor diameter }\end{array}$ \\
& $\begin{array}{c}\text { distance with spindle } \\
\text { speed 109 rpm) }\end{array}$ & $\begin{array}{c}\text { with spindle } \\
\text { speed 109 rpm) }\end{array}$ & $\begin{array}{c}\text { With spindle } \\
\text { speed 109 rpm) }\end{array}$ \\
\hline 1 & 1.5985 & 14.9940 & 13.1890 \\
2 & 1.5140 & 14.9630 & 13.2755 \\
3 & 1.5789 & 14.9365 & 13.2750 \\
4 & 1.5798 & 14.9830 & 13.1795 \\
5 & 1.5980 & 14.9605 & 13.2040 \\
6 & 1.5752 & 14.9835 & 13.2465 \\
7 & 1.5190 & 14.9750 & 13.2475 \\
8 & 1.5130 & 14.9725 & 13.2345 \\
9 & 1.5650 & 14.9335 & 13.2035 \\
10 & 1.5165 & 14.9730 & 13.2080 \\
\hline Nilai rata-rata & $\mathbf{1 5 . 3 0 9 5}$ & $\mathbf{1 4 9 . 4 9 4 5}$ & $\mathbf{1 3 2 . 1 9 3 5}$ \\
\hline
\end{tabular}

From the thread pitch distance measurement data, the average value and standard deviation can be calculated, where the calculation of the average value of the total measurement and calculating the standard deviation value is carried out. The results, calculations are obtained in Table 2.

Table 2. Result, Calculation of Mean and Standard Deviation

\begin{tabular}{lccc}
\hline & $\begin{array}{c}\text { Sample A } \\
\text { (Thread pitch distance with } \\
\text { spindle speed 109 rpm) }\end{array}$ & $\begin{array}{c}\text { Sample B } \\
\text { (Major diameter with } \\
\text { spindle speed 109 rpm) }\end{array}$ & $\begin{array}{c}\text { Sample C } \\
\text { (Minor diameter with } \\
\text { spindle speed 109 rpm) }\end{array}$ \\
\hline$\overline{\boldsymbol{x}}$ & 1.53095 & 14.94945 & 13.21935 \\
$\boldsymbol{\delta}^{\mathbf{2}}$ & 0.00018 & 0.00074 & 0.01237 \\
$\boldsymbol{\delta}$ & 0.01346 & 0.02720 & 0.11122 \\
\hline
\end{tabular}

In sample $\mathrm{A}$, the thread pitch distance has an average distance of $1.530 \mathrm{~mm}$ with a standard deviation of $0.01346 \mathrm{~mm}$, sample B shows the major diameter has an average distance of $14.949 \mathrm{~mm}$ with a standard deviation of $0.02720 \mathrm{~mm}$, and sample $\mathrm{C}$ shows the minor diameter has a distance an average of $13.2193 \mathrm{~mm}$ with a standard deviation of $0.11122 \mathrm{~mm}$. The lower the value of the standard deviation, the closer to the average, whereas if the value of the standard deviation is higher, the wider the variation of the data. 


\section{CONCLUSIONS}

From the results of the measurement of the thread pitch distance with 10 measurements in each sample, the average value, variance (variance), and standard deviation (standard deviation) are obtained. In sample A, the thread pitch distance has an average distance of $1.530 \mathrm{~mm}$ with a standard deviation. $0.01346 \mathrm{~mm}$. In sample B, the major diameter distance has an average distance of $14.494 \mathrm{~mm}$ with a standard deviation of $0.02720 \mathrm{~mm}$. In sample $\mathrm{C}$, the distance of the minor diameter has an average distance of $13.2193 \mathrm{~mm}$ with a standard deviation of $0.11122 \mathrm{~mm}$.

\section{SUGGESTIONS}

The suggestions that the author wants to convey from this research and measurement are:

1. In this research, it is expected to use the machining process of the test object using a CNC lathe to produce a more precise size.

2. To get a precise and accurate value in further research, it is expected to add a measurement sample and a comparison of the sample to the object being tested to get more accurate results.

3. In further research, it is expected to add a comparison of the sample of the test object with the form of a graph so that it is easily understood by the reader

\section{REFERENCES}

[1] "DASAR-DASAR METROLOGI INDUSTRI: Bab IV - Pengukuran Ulir,” Staff Site Universitas Negeri Yogyakarta. Yogyakarta, pp. 149-177, 2011, [Online]. Available: http://staffnew.uny.ac.id/upload/130681036/pendidikan/Pengukuran+Ulir.pdf.

[2] D. Rahdiyanta, "MATERI KULIAN PROSES PEMESINAN KERJA BUBUT - Pemeriksaan Kesesuaian Antara Komponen Dan Spesifikasi." Yogyakarta, pp. 1-7, [Online]. Available: http://staffnew.uny.ac.id/upload/131569341/pendidikan/kerja-bubut-pemeriksaan-kesesuaian.pdf.

[3] B. T. Hatnolo, "Pengukuran Dimensi Roda Gigi Lurus Menggunakan Mesin Profile Projector." Universitas Pamulang Digital Repository, Kota Tangerang Selatan, 2018, [Online]. Available: http://eprints.unpam.ac.id/8177/.

[4] M. Badri, D. S. Arief, A. M. Solih, D. Ayunita, and A. Muflihana, "Sieving Machine Calibration Using a Profile Projector with Standard Method ASTM E-11 2004," J. Ocean. Mech. Aerosp. - Sci. Eng., vol. 57, pp. 1-4, 2018, [Online]. Available: http://isomase.org/Journals/index.php/jomase/article/view/25.

[5] H. U. Wibowo, "Analisa Pengaruh Hasil Pengukuran Ketirusan Terhadap Senter Tetap Mesin Bubut Menggunakan Profile Projector." Universitas Pamulang Digital Repository, Kota Tangerang Selatan, 2018, [Online]. Available: http://eprints.unpam.ac.id/5836/. 